\title{
経ロメチルセルロース液剤のゲル化に及ぼす保存温度の影響
}

\author{
下山哲哉，宮城由莉子，伊藤邦彦，小林道也*
}

\section{Effect of Storage Temperature on Gelation of Oral Methylcellulose Formulation}

\author{
Tetsuya Shimoyama, Yuriko Miyagi, Kunihiko Itoh, and Michiya Kobayashi* \\ Department of Pharmaceutics (Clinical Pharmaceutics), School of Pharmaceutical Sciences, Health Sciences \\ University of Hokkaido; 1757 Kanazawa, Tobetsu-cho, Ishikari-gun, Hokkaido 061-0293, Japan.
}

(Received January 7, 2013; Accepted March 12, 2013)

\begin{abstract}
Heating a methylcellulose solution forms a thermal-reversible hydrogel. After the hydrogel forms, its properties change according to its temperature. However, the effects of heating this solution during storage and then cooling it are unclear. We investigated the effects of this heating and cooling on rheological and drug release characteristics. We prepared samples of methylcellulose solution (2\% methylcellulose and $20 \%$ D-sorbitol) and examined them under two conditions: 1) storage for 24 hours at 4 to $30^{\circ} \mathrm{C}$, 2) storage for 24 hours at 4 to $50^{\circ} \mathrm{C}$, then cooling to $4^{\circ} \mathrm{C}$ and maintained for 4 hours. We performed rheological investigations of viscosity, gelation temperature and gel strength, and examined the drug release characteristics by using a diffusion cell method with acetaminophen as the model drug. It was found that as the storage temperature rose, the methylcellulose solution increased in viscosity and the gelation temperature and gel strength changed. During storage at $30^{\circ} \mathrm{C}$, the amount of drug released by the solution increased and the diffusion coefficient was high. When cooled to $4^{\circ} \mathrm{C}$, the solution recovered its viscosity, gelation temperature, gel strength and drug release characteristics, regardless of the previous storage temperature. These results clarify that although the rheological and drug release characteristics of methylcellulose solution change with changes in storage temperature, the original characteristics are recovered after the solution is cooled to $4^{\circ} \mathrm{C}$ and maintained at that temperature for four hours.
\end{abstract}

Key words — methylcellulose; gelation; storage temperature; drug release

\section{緒言}

メチルセルロースは，セルロースを構成するグル コース残基の水酸基を化学的にメチル化した半合成 高分子で, 食品や医薬品の増粘剂, 懸濁化剂及び コーティング剂としても広く用いられている. メチ ルセルロース水溶液は低温ではゾル状態で, メチル セルロース分子と水和している. しかし，温度の上 昇によって，メチルセルロース分子は段階的に水和 水を失い, メチル基置換度の高い疎水性領域で分子 間の会合が起こる，その結果，メチルセルロース分 子が凝集して，粘度及び濁度の急激な上昇を経てゲ ル化する. ${ }^{1-4)}$ メチルセルロース水溶液のゲル化温

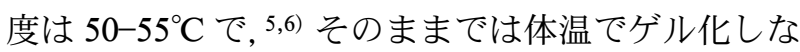
い. しかし，塩析力の高い無機塩7-9) あるいは糖ア ルコール 10)の添加により， メチルセルロース分子の

The authors declare no conflict of interest. 北海道医療大学薬学部薬剂学講座 (臨床薬剂学)

*e-mail: platypus@hoku-iryo-u.ac.jp
脱水和が促進され，メチルセルロース水溶液のゲル 化温度を体温 $\left(37^{\circ} \mathrm{C}\right)$ 以下まで低下させることも可 能である. わかもと製薬株では，メチルセルロースー マクロゴール 4000-クエン酸ナトリウム混合系を用 いて，ヒト体温でゲル化するリズモン ${ }^{\circledR} \mathrm{TG}$ 点眼 液, ${ }^{11,12)}$ 及びオフロキサシンゲル化点眼液 $0.3 \%$ 「わかもと」13)を上市している。これらの点眼液は投 与前にはゾル状態であるが，眼表面温度でゲル化す ることにより, 薬物徐放性や結膜囊内の滞留性が向 上している.

われわれは先に，2\%メチルセルロース水溶液に 糖アルコールの 1 つで, 矯味剤としても用いられる D-ソルビトールを $20 \%$ 添加すると, メチルセル ロース分子の脱水和が促進され，ゲル化温度が体温 以下に低下する特性を応用し, ${ }^{10,14)}$ 胃内で温度（体 温）に応答してゲル化することにより薬物放出を制 御する経口徐放性液剂の設計を行ってきた. ${ }^{14-16)}$ 本 液剤は加温に伴いゲル化することから，保存時及び 服用時の温度によって異なる物性を示すことが推測 
される，前述のメチルセルロース点眼液のインタビ ユーフォームには「しゃ光, $10^{\circ} \mathrm{C}$ 以下に保存」, ${ }^{11,13)}$ 添付文書には，「本剂は熱応答ゲル製剤のため，室 温中に放置するとゲル化することがあるので，本剂 がゲル化した場合は冷蔵庫等で冷却してから点眼す ること」, ${ }^{17}$,18) と記載されている。したがって，わ れわれが設計したメチルセルロース液剤も同様に, 保存温度には十分な注意が必要であることが考えら れる。

メチルセルロース分子の温度による凝集には 3 段 階があることが知られており，低い温度から順に， ゾル状態，一時的な凝集状態，ゲル状態に分類され る. ${ }^{19)}$ メチルセルロース分子の凝集状態は温度によ って異なることから，メチルセルロース液剤は調製 後の温度変化により, 形成するゲルの性質も変化す ることが予想される。このことは，患者が本剤を保 管あるいは携帯するときの温度変化，また服用時の 温度により，粘度や胃内でゲル化した際の薬物徐放 性が変化する可能性が考えられるが，詳細に検討し た報告はない，そこで，本研究ではメチルセルロー ス液剤の保存温度が及ぼすレオロジー的性質及び液 剤からの薬物放出への影響について評価し，本剤の 保存上の注意点を明らかにすることを目的とした.

\section{方法}

\section{1. 実験材料 メチルセルロース（MCE-400,}

Lot. 7105564, 粘度グレード $400 \mathrm{mPa} \cdot \mathrm{s})$ は，信越 化学工業秼より供与されたものを使用した。 アセト アミノフェン（ピリナジン®）は，長生堂製薬侏 より購入したものを使用した。 D-ソルビトールは, 和光純薬工業侏より購入したものを使用した。その 他実験に供した試薬は市販特級規格以上のものを使 用した。

2. 液剂の調製 $2 / 3$ 容の超純水中に D-ソルビ トールを溶解し， $70-80^{\circ} \mathrm{C}$ に加温した後にメチルセ ルロースを加え，均一に分散するまで靦汼した。そ の後, $50^{\circ} \mathrm{C}$ で 1 時間, さらに氷冷下で 1 時間攪拌 してメチルセルロースを完全に溶解し，最後に超純 水を加えて容積を調整した。 薬物（アセトアミノフ エン）を含有する液剤は， $50^{\circ} \mathrm{C}$ で攪汼する時点で アセトアミノフェンを添加して溶解し，以下同様に 調製した。最終濃度はメチルセルロース $2.0 \%$ （w/ v)，D-ソルビトール $20 \%$ (w/v)，及びアセトアミ
ノフェン $1 \%(\mathrm{w} / \mathrm{v})$ である.

3. 液剤の保存条件 インキュベータ（MIR153 , 三洋電機侏) 中, $4,10,15,20,25,30^{\circ} \mathrm{C}$ で 24 時間静置したメチルセルロース液剤，及び 10,15 , $20,25,30,37,50^{\circ} \mathrm{C}$ で 24 時間静置した後， $4{ }^{\circ} \mathrm{C}$ で 4 時間冷却した液剤を実験に用いた。

4. 粘度の測定 $\mathrm{E}$ 型粘度計 $(\mathrm{TV}-20 \mathrm{H}$, model $\mathrm{E}$ ，東機産業侏） にコーン・ロー夕 $\left(1^{\circ} 34^{\prime} \times \mathrm{R} 24\right)$ を取り付けて測定した。メチルセルロース液剤（薬 物非添加） $1 \mathrm{~mL}$ をロー夕内に注入し， $20^{\circ} \mathrm{C}$ で 30 分静置後, 回転速度 $6,12,30,60 \mathrm{rpm}$ （ずり速度 $\left.22.89,45.96,114.9,228.9 \mathrm{~s}^{-1}\right)$ における粘度をそれ ぞれ測定した．なお，30 分の静置により，いずれ の温度条件の試料も $20 \pm 0.5^{\circ} \mathrm{C}$ 以内になっているこ とを確認した。

5. ゲル化温度の測定 音叉型振動式粘度計 （SV-10，侏エー・アンド・デイ）を用いて測定し た。 $4^{\circ} \mathrm{C}$ に冷却したメチルセルロース液剤（薬物非 添加） $10 \mathrm{~mL}$ を，恒温循環装置（NCB-1200，東京 理化器械侏）を用いて, 液剤が $60^{\circ} \mathrm{C}$ になるまで加 温した，液剤の温度上昇により変化する粘度を経時 的に測定し，粘度が減少から増加に転じる変曲点の 温度をゲル化温度とした。

6. ゲルの破断強度解析 試料のゲルは, 各保 存温度で 24 時間静置したメチルセルロース液剤

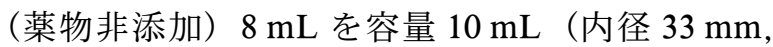
高さ $10 \mathrm{~mm}$ ) のシャーレに入れ，インキュベータ (MIR-153，三洋電機侏) $)$ 中， $37^{\circ} \mathrm{C}$ で 24 時間静置 して調製した。破断強度解析は，レオメーター （RHEOMETER CR-500DX，侏サン科学）を用い て行った．試料のゲルが入ったシャーレを試料台に 載せ，直径 $2.0 \mathrm{~cm}$ のプランジャーを用い，試料台 の上昇速度は $60 \mathrm{~mm} / \mathrm{min}$ で測定した。試験開始 後，ゲルが破断されて応力（stress）が大きく低下 する点における荷重をゲル強度とした。また，プラ ンジャーが移動した距離を, 試料の厚みで除して歪 み（strain）とした。

7. In vitro 薬物放出実験 液剤からのアセ卜 アミノフェンの放出実験は, Miyazaki らの方法に 従い，拡散セル法により行った. ${ }^{20)}$ 各セルの容積は $4 \mathrm{~mL}$ で，セルロース膜（Viskase, Inc.）の表面積 は $2.67 \mathrm{~cm}^{2}$ である. Donor 側には，アセトアミノ フェンを含有する液剤を $4 \mathrm{~mL}$, receptor 側には同 
量の第十六改正日本薬局方（JP16）崩壊試験第 1 液を入れ， $37^{\circ} \mathrm{C}$ の恒温槽中にて， 60 strokes $/ \mathrm{min}$ で 振とうし, 経時的に receptor 側の試験液を採取し た。試験液中の薬物濃度は分光光度計 (UV-1800, 秼島津製作所）を用いて，244 nm における吸光度 を測定して算出した。 Receptor 側の試験液は経口 投与時を想定して, 開始 1 時間までは崩壊試験第 1 液（pH 1.2），引き続き 5 時間は第 2 液（pH 6.8） を使用し，合計 6 時間実施した。

ゲルからの累積薬物放出量を半固形製剤からの薬 物放出に関する Higuchi の拡散モデル (Eq. 1) ${ }^{21)}$ に より解析し，拡散定数 $D$ を算出した。 ここで， $C_{0}$ は薬物の初濃度, $Q$ は単位面積当たりの累積放出 薬物量, $t$ は時間である.

$$
Q=2 C_{0}\left(\frac{D_{t}}{\pi}\right)^{\frac{1}{2}}
$$

8. 統計学的処理 測定值は. 平均值土標準誤 差（means \pm S.E.） で示した。 Dunnett の一元配置 分散分析及び Student の $t$ 検定により検定を行い, 危険率 $5 \%$ をもって統計学的に有意とした.

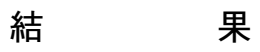

1. 粘度 $20 \% \mathrm{D}$-ソルビトールを添加したメチ ルセルロース水溶液のゲル化温度は $37^{\circ} \mathrm{C}$ 以下であ ることから, ${ }^{10,14)} 4^{\circ} \mathrm{C}$ から $30^{\circ} \mathrm{C}$ の条件で保存した液 剂, 並びに $20^{\circ} \mathrm{C}$ から $50^{\circ} \mathrm{C}$ の条件で保存後, $4^{\circ} \mathrm{C}$ に
冷却した液剤について粘度の測定を行つた。メチル セルロース液剤は保存温度にかかわらず，ずり速度 の増加に伴い粘度が減少する, 非ニュートン流動性 を示した（Fig. 1)。また， $25^{\circ} \mathrm{C}$ 及び $30^{\circ} \mathrm{C}$ で保存し たとき，低ずり速度では， $4^{\circ} \mathrm{C}$ 及び $20^{\circ} \mathrm{C}$ で保存し たものよりも粘度は高い值を示したが，高ずり速度 では，同程度の值を示した [Fig. 1(A)]。一方，加 温後に $4^{\circ} \mathrm{C}$ に冷却した液剤では，一度 $50^{\circ} \mathrm{C}$ で保存 した液剤は他の液剤と比較して, 若干低い值を示し たが，他の保存温度では，いずれのずり速度におい ても粘度に大きな変化はみられなかった [Fig. 1 (B) ].

2. ゲル化温度 $15^{\circ} \mathrm{C}$ から $25^{\circ} \mathrm{C}$ の条件で保存 したメチルセルロース液剤のゲル化温度は， $4^{\circ} \mathrm{C}$ で 保存したものと比較して有意に高い值を示したが, $30^{\circ} \mathrm{C}$ で保存したものでは, $4^{\circ} \mathrm{C}$ で保存したものと同 程度の值まで低下し，その差は認められなかった (Fig. 2). 一方, 加温後に $4^{\circ} \mathrm{C}$ まで冷却したメチル セルロース液剤は，保存温度にかかわらず，ゲル化 温度に変化は認められなかった。

3. ゲルの破断強度解析 メチルセルロース液 剤から調製したゲルの強度は，保存温度を $4^{\circ} \mathrm{C}$ から $20^{\circ} \mathrm{C}$ とした条件では温度の上昇に伴って増大した が， $25^{\circ} \mathrm{C}$ 及び $30^{\circ} \mathrm{C}$ ではゲルの強度は低下した [Fig. 3 (A) ]. 一方，加温後に冷却したメチルセル ロース液剤のゲル強度には，大きな変化は認められ
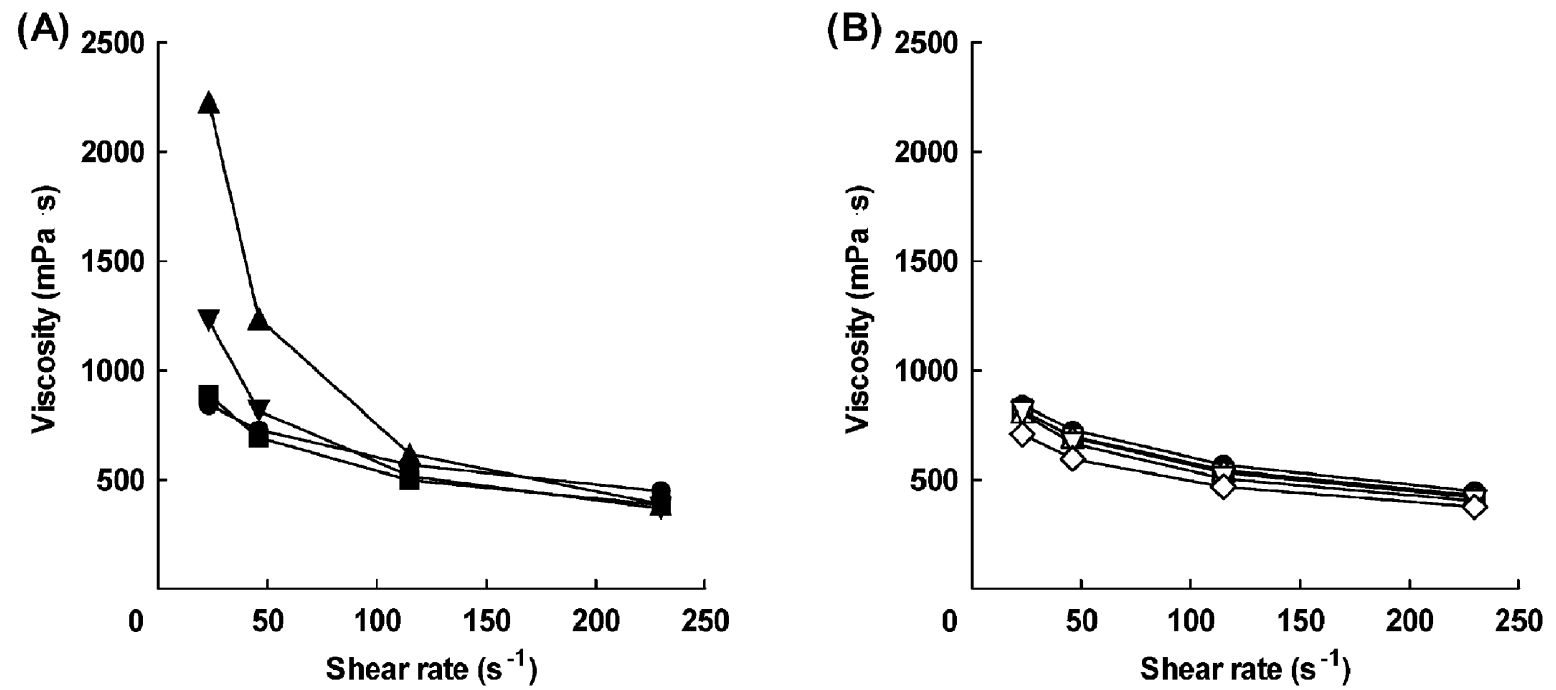

Fig. 1. Effect of Storage Temperature on Shear-rate-dependent Viscosity at $20^{\circ} \mathrm{C}$ for Methylcellulose Formulation Stored at (A) $4{ }^{\circ} \mathrm{C},(\boldsymbol{\square}) 20^{\circ} \mathrm{C},(\nabla) 25^{\circ} \mathrm{C}$, and $(\boldsymbol{\Delta}) 30^{\circ} \mathrm{C},(\mathrm{B})(\boldsymbol{O}) 4^{\circ} \mathrm{C},(\square) 20^{\circ} \mathrm{C},(\triangle) 30^{\circ} \mathrm{C},(\nabla) 37^{\circ} \mathrm{C}$, and $(\diamond) 50^{\circ} \mathrm{C}$ for $24 \mathrm{~h}$, then Cooled to $4{ }^{\circ} \mathrm{C}$ for $4 \mathrm{~h}$

Values are means \pm S.E. of 3 determinations, but most of the error bars are hidden behind the symbols. 
ず，応力ーひずみ曲線の原点近傍の傾きはほぼ等し

く，同様の弾性を示した [Fig. 3(B)].

4. In vitro 薬物放出実験 $20^{\circ} \mathrm{C}$ で保存した液 剂は試験開始後セル内でゲルを形成し，保存温度 4

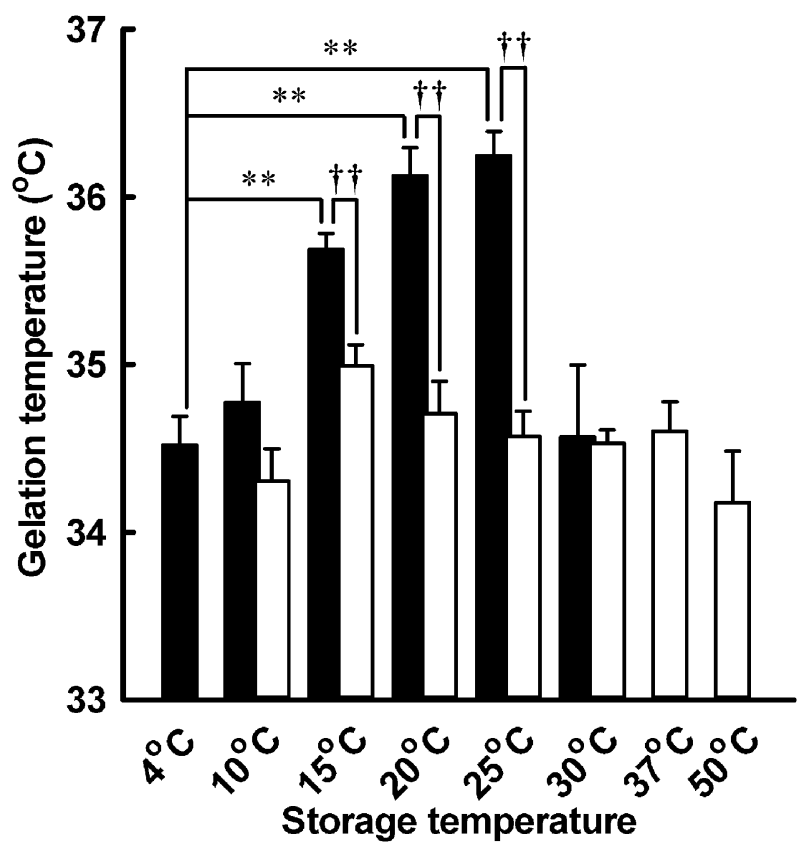

Fig. 2. Effect of Storage Temperature on Gelation Temperature of Methylcellulose Solution without (black bar) and with (white bar) 4-h cooling at $4^{\circ} \mathrm{C}$

Values are means \pm S.E. of 3 determinations. ${ }^{* *} p<0.01$, significantly different from the solution kept at $4{ }^{\circ} \mathrm{C} .{ }^{\# \dagger} p<0.01$, significantly different from the solution without cooling.

(A)

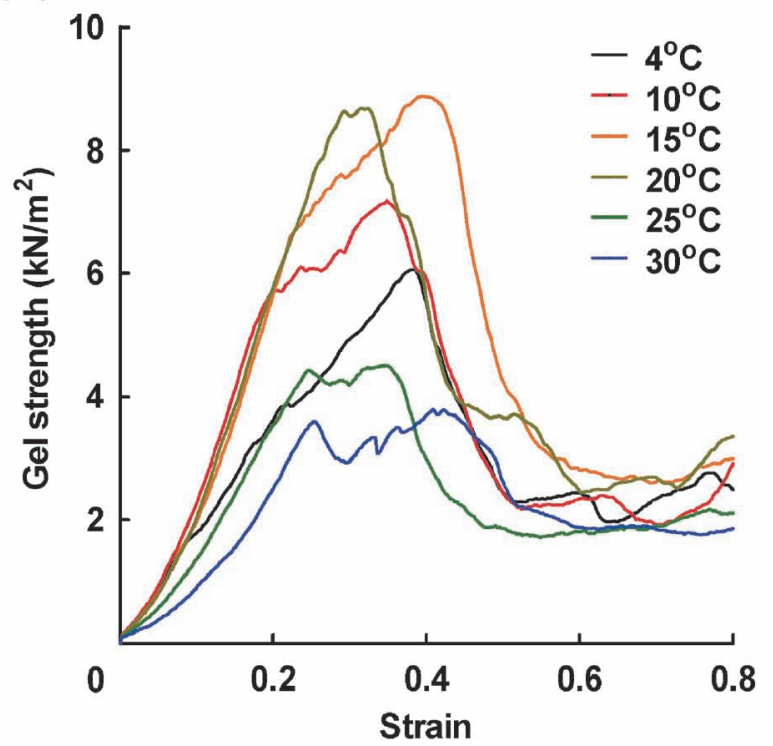

${ }^{\circ} \mathrm{C}$ と同様の薬物放出挙動を示した。一方， $30^{\circ} \mathrm{C}$ で 保存したメチルセルロース液剂も同様にゲルを形成 したが，薬物放出量は $4^{\circ} \mathrm{C}$ で保存したものと比較し て若干増加した $[$ Fig. 4(A) ]。 また，薬物放出量の 増大に伴い, 保存温度 $30^{\circ} \mathrm{C}$ における拡散定数は，4 ${ }^{\circ} \mathrm{C}$ と比較して有意に高い值を示した（Table 1)。一 方，ゲル化温度以上である $37^{\circ} \mathrm{C}$ 及び $50^{\circ} \mathrm{C}$ に加温後 $4^{\circ} \mathrm{C}$ に冷却したメチルセルロース液剂では，一度ゲ ル化後，ゾルに再転移したにもかかわらず，終始 4 ${ }^{\circ} \mathrm{C}$ で保存した液剂と同様の薬物放出挙動を示した [Fig. 4(B)]。 また，拡散定数に差はほとんど認め られなかつたことから，薬物放出制御能は同等であ ることが示された (Table 1).

Table 1. Diffusion Coefficients, D, for In Vitro Release of Acetaminophen from Methylcellulose Gel Formulations at $37^{\circ} \mathrm{C}$

\begin{tabular}{cc}
\hline \hline Storage temperature $\left({ }^{\circ} \mathrm{C}\right)$ & $D\left(\times 10^{-6} \mathrm{~cm}^{2} / \mathrm{s}\right)$ \\
\hline 4 & $5.42 \pm 0.05$ \\
20 & $5.15 \pm 0.16$ \\
30 & $7.97 \pm 0.80^{* *}$ \\
$37 \rightarrow 4$ & $5.98 \pm 0.67$ \\
$50 \rightarrow 4$ & $5.29 \pm 0.15$
\end{tabular}

Values are means \pm S.E. of 4 determinations. $* * p<0.01$, significantly different from that stored at $4^{\circ} \mathrm{C}$.

(B)

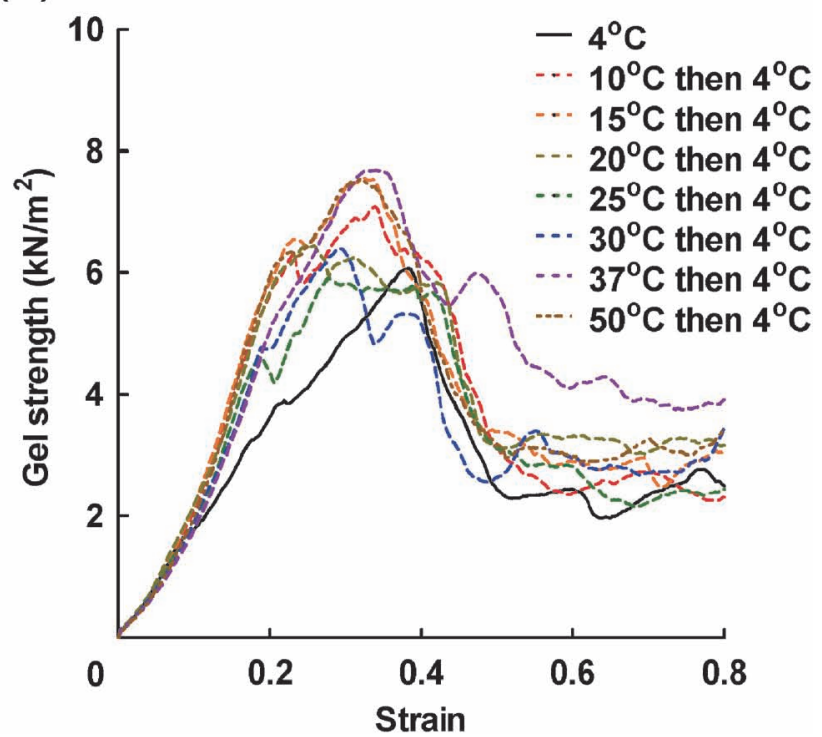

Fig. 3. Stress-strain Curves of Methylcellulose Gels Prepared at $37^{\circ} \mathrm{C}$ after 24 -h Storage at (A) $4-30^{\circ} \mathrm{C}$ and (B) $4-50^{\circ} \mathrm{C}$ Followed by 4-h Cooling at $4^{\circ} \mathrm{C}$ 
(A)

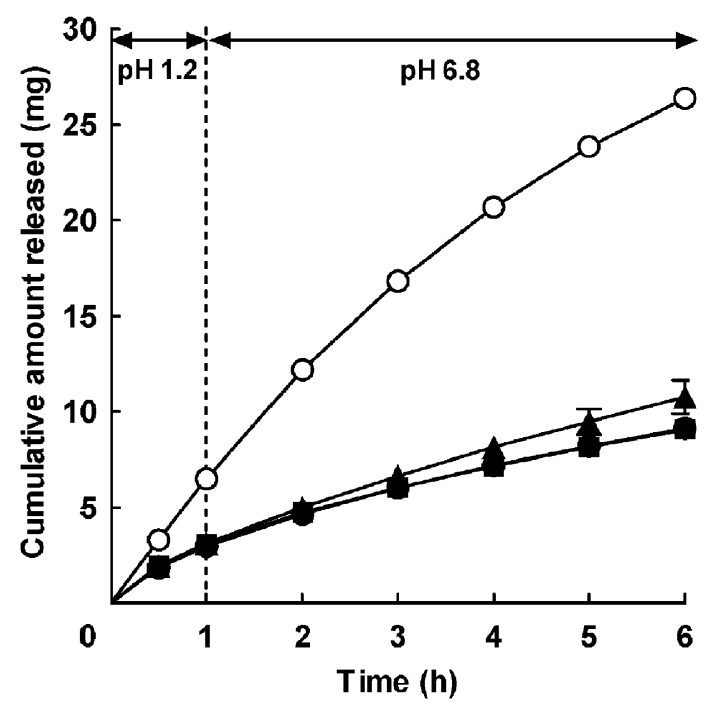

(B)

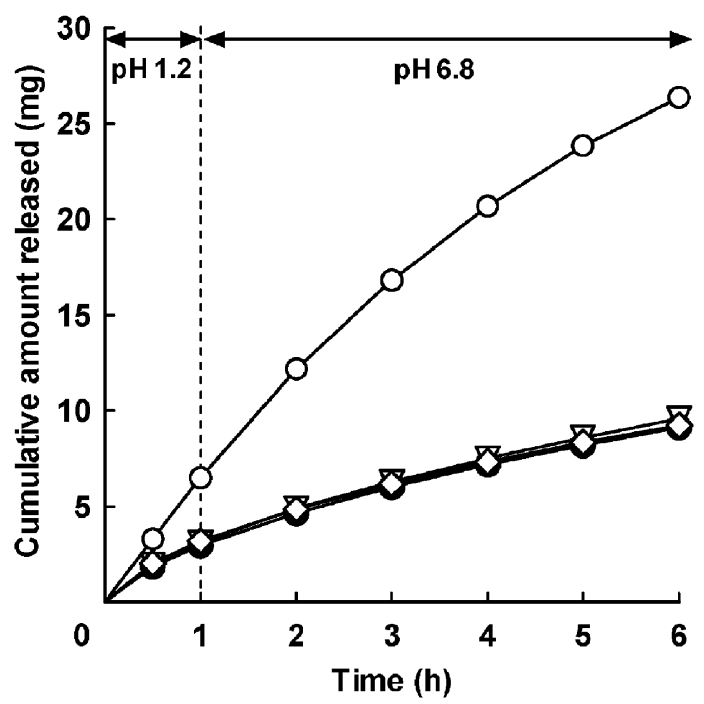

Fig. 4. Cumulative In Vitro Release of Acetaminophen as a Function of Time from (A) (O) Aqueous Solution and Methylcellulose Gels Stored for $24 \mathrm{~h}$ at $(-) 4^{\circ} \mathrm{C},(\boldsymbol{\square}) 20^{\circ} \mathrm{C}$, and $(\boldsymbol{\Delta}) 30^{\circ} \mathrm{C},(\mathrm{B})(\nabla) 37^{\circ} \mathrm{C}$, and $(\diamond) 50^{\circ} \mathrm{C}$, then Cooled for $4 \mathrm{~h}$ at $4{ }^{\circ} \mathrm{C}$

Release was into simulated gastric fluid of $\mathrm{pH} 1.2$ for a period of $1 \mathrm{~h}$ and subsequently into simulated intestinal fluid of pH 6.8 at $37^{\circ} \mathrm{C}$. Values are means \pm S.E. of 4 determinations, but most error bars are hidden behind symbols.

考察

メチルセルロース水溶液は加温すると，メチルセ ルロース分子から段階的に水和水が失われ，メチル 基置換度の高い疎水性領域で凝集が起こる。ささらに 温度が上昇すると凝集して，ゲル化する. ${ }^{22)}$ 一方, 加温されたメチルセルロース水溶液は冷却すると, メチルセルロース分子の水和が回復することで，疎 水的相互作用は消失し，7,23,24) ゲルはゾルに再転移 するとともに，粘度は加温前の状態まで低下する. このメチルセルロースのゾルーゲル転移には，単に ゾル，ゲルだけでなく，メチルセルロース分子の一 時的な凝集状態が中間に存在することから，19）水溶 液の温度変化はゲル化温度や形成するゲルの強度及 び弾性になんらかの影響を及ぼすことが考えられる.

はじめに，メチルセルロース液剤の粘度に対する 保存温度の影響を検討した。 $25^{\circ} \mathrm{C}$ 及び $30^{\circ} \mathrm{C}$ でメチ ルセルロース液剤を保存すると，加温によってメチ ルセルロース分子の凝集が進行したため, 低いずり 速度では $4^{\circ} \mathrm{C}$ で保存した液剤よりも高い粘度を示 し, ずり速度の増大に伴って, 弱い凝集状態が破壊 され， $4^{\circ} \mathrm{C}$ で保存した液剤と同程度の粘度まで低下 したと考えられた。一方，加温した液剤を $4^{\circ} \mathrm{C}$ に冷 却したところ, 終始 $4{ }^{\circ} \mathrm{C}$ で保存した液剂と同様の粘
性挙動を示した [Fig. 1(B)]。これは，冷却によっ てメチルセルロース分子が再水和され，疎水性領域 間の相互作用が消失して加温前のゾル状態に戻った ためと考えられた. ${ }^{7,23,24)}$

次に保存温度がゲル化温度に及ぼす影響を評価し た。 $4^{\circ} \mathrm{C}$ から $30^{\circ} \mathrm{C}$ の条件で保存したメチルセル ロース液剤のゲル化温度を測定したところ，保存温 度 $15^{\circ} \mathrm{C}$ から $25^{\circ} \mathrm{C}$ にかけてゲル化温度が上昇した (Fig. 2)。これらの温度で加温されたメチルセル ロース分子は凝集し, この状態からのゲル化には, より大きなエネルギーを要することが示唆された. 対して, $30^{\circ} \mathrm{C}$ で保存した場合, $4^{\circ} \mathrm{C}$ と比較して粘度 は増大したが [Fig. 1(A)]，ゲル化温度は変化しな かった。これは $30^{\circ} \mathrm{C}$ ではメチルセルロース分子は ゲル化する前の凝集状態にあるものの, $25^{\circ} \mathrm{C}$ と比 べて凝集が進行し，凝集状態からのゲル化に必要な エネルギーが減少した結果, 保存温度 $4^{\circ} \mathrm{C}$ の液剤と 同程度のゲル化温度を示したと推測された。また, 加温後 $4^{\circ} \mathrm{C}$ に冷却した液剤では, 保存温度によるゲ ル化温度の差は認められなかった。これは粘度と同 様，冷却によりメチルセルロース分子の凝集が解か れたためと考えられた.

本メチルセルロース液剂は, 胃内でゲル化して薬 物放出を抑制する。そのため，形成するゲルには， 
徐放性の持続及び消化管内滞留性の観点から，ある 程度の強度や弾性が求められる。 そこで， $4^{\circ} \mathrm{C}$ から $30^{\circ} \mathrm{C}$ の条件で保存したメチルセルロース液剤から 調製したゲルの強度を測定した。 $4^{\circ} \mathrm{C}$ から $20^{\circ} \mathrm{C}$ の 条件で保存した液剤から調製したゲルでは，保存温 度の上昇に伴い，メチルセルロース液剤のゲル強度 は増大したが, 保存温度 $25^{\circ} \mathrm{C}$ 及び $30^{\circ} \mathrm{C}$ ではゲル強 度が低下した $[\mathrm{Fig} .3(\mathrm{~A})] .4{ }^{\circ} \mathrm{C}$ から $20^{\circ} \mathrm{C}$ で保存 された液剤は，保存温度の上昇に伴ってメチルセル ロース分子の運動性は増大しており，この状態から 加温されると，架橋点でより密な凝集が生じ，ゲル 化したと考えられた。一方， $25^{\circ} \mathrm{C}$ 及び $30^{\circ} \mathrm{C}$ で保存 した液剂では，先の粘度測定の結果から示唆された ように，メチルセルロース分子は一時的な凝集状態 にある。このゲル化に至らない弱い凝集状態から加 温されると，メチルセルロースの分子運動が制約さ れるため, 架橋点における分子凝集が不十分になっ た結果，ゲル強度が低下したと考えられた。一方， 加温後 $4^{\circ} \mathrm{C}$ に冷却した液剂から調製したゲルでは, 応力ーひずみ曲線に変化がほとんど認められなかっ たことから [Fig. 3(B)]，ゲル調製直前の保存温度 が，ゲルの強度及び弾性に影響することが示唆され た.

最後に, 保存温度が液剂からの薬物放出性に及ぼ す影響を明らかにするため, 薬物放出性を拡散セル 法で評価した。保存温度 $20^{\circ} \mathrm{C}$ のメチルセルロース 液剤の薬物放出挙動は $4^{\circ} \mathrm{C}$ で保存したものと同様で あったのに対して，保存温度 $30^{\circ} \mathrm{C}$ の液刘では累積 薬物放出量, 及び拡散定数の増大が確認された [Fig. 4(A) and Table 1]。保存温度 $30^{\circ} \mathrm{C}$ の液剂で は，メチルセルロース分子はゲル化する前の一時的 な凝集状態にあり，これが $37^{\circ} \mathrm{C}$ に加温されると， 他の保存条件の液剤に比べて, 密度が疎なゲルを形 成し，薬物がゲルマトリックス内をより容易に移動 したためと考えられる.この薬物放出挙動の変化の 程度は，水溶液と比較すると十分に低いものの，経 口投与した場合，液剤からの薬物放出性に若干の影 響を及ぼすことが示唆された。一方，加温後 $4^{\circ} \mathrm{C} に$ 冷却した液剤では，薬物放出挙動に変化は認められ なかった [Fig. 4(B)]。したがって，メチルセル ロース液剤からの薬物放出は $30^{\circ} \mathrm{C}$ における保存時 に増大するが，十分に冷却することで薬物放出制御 能は回復することが明らかになった。
本研究より，メチルセルロース液剂は薬物徐放性 を発揮させるには， $4^{\circ} \mathrm{C}$ から $20^{\circ} \mathrm{C}$ で保存するのが 望ましいが，それ以上の温度で保存した場合も冷蔵 庫などで数時間冷却することで，問題なく使用でき ることが明らかになった。メチルセルロースは温度 応答性高分子として、ゾルーゲル転移を利用した製 剤の設計に有用な基剂である。しかし，そのゲル形 成性は単なるゾルーゲル転移によるものではなく， 保存温度によっては同じゾル状態であっても，メチ ルセルロース分子の凝集状態によって，ゲル化した 際の物性が変化する。本研究から得られた知見は, メチルセルロース液剤を安全かつ有効な薬物療法に 適用する上で重要である。また，患者や医療関係者 への製剂の取り扱い方法，製造後の流通及び品質管 理などの観点からも，必要不可欠な情報が得られた と考える.

\section{謝辞ここの実験の一部は, 科学研究費助成事業} (学術研究助成基金助成金（若手研究（B）課題番 号 24790165)）により行われた。また，メチルセ ルロースを供与頂いた信越化学工業怢に深く感謝致 します。

\section{REFERENCES}

1) Nakagawa A., Steiniger F., Richter W., Koschella A., Heinze T., Kamitakahara H., Langmuir, 28, 12609-12618 (2012) .

2) Haque A., Jones A. K., Richardson R. K., Morris E. R., Carbohydr. Polym., 22, 291300 (1993).

3) Kobayashi K., Huang C., Lodge T. P., Macromolecules, 32, 7070-7077 (1999).

4) Takeuchi M., Kageyama S., Suzuki H., Wada T., Notsu Y., Ishii F., Colloid Polym. Sci., 281, 1178-1183 (2003).

5) Kunisaki N., Sano M., "Food Technology, Food Polysaccharides," Saiwai Shobo Co., Ltd., Tokyo, 2001, pp. 180-193.

6) Feller R. L., Wilt M., "Evaluation of Cellulose Ethers for Conservation," The Getty Conservation Institute, Marina del Rey, 1990.

7) Xu Y., Wang C., Tam K. C., Li L., Langmuir, 20, 646-652 (2004).

8) Liang H. F., Hong M. H., Chung C. K., Lin Y. H., Chen C. H. Sung H. W., Biomacro- 
molecules, 5, 1917-1925 (2004).

9) Xu Y., Li L., Zheng P., Lam Y. C., Hu X., Langmuir, 20, 6134-6138 (2004).

10) Levy G., Schwarz T. W., J. Am. Pharm. Assoc., 47, 44-46 (1958).

11) Interview Form, Rysmon ${ }^{\circledR} \mathrm{TG}$ Ophthalmic Solution $0.25 \% / 0.5 \%$, 5th ed., Wakamoto Co., Ltd., 2010.

12) Takeuchi M., Gekkan Yakuji, 51, 1305-1309 (2009).

13) Interview Form, Ofloxacin Gel Forming Ophthalmic Solution 0.3\%「Wakamoto」, 1st ed., Wakamoto Co., Ltd., 2008.

14) Itoh K., Hatakeyama T., Kimura T., Shimoyama T., Miyazaki S., D’Emanuele A., Attwood D., Chem. Pharm. Bull., 58, 247-249 (2010).

15) Itoh K., Hatakeyama T., Shimoyama T., Miyazaki S., D’Emanuele A., Attwood D., Drug Dev. Ind. Pharm., 37, 790-797 (2011) .

16) Shimoyama T., Itoh K., Kobayashi M., Miya- zaki S., D’Emanuele A., Attwood D., Drug Dev. Ind. Pharm., 38, 952-960 (2012).

17) Package Insert, Rysmon ${ }^{\circledR}$ TG Ophthalmic Solution $0.25 \% / 0.5 \%$, 7 th ed., Wakamoto Co., Ltd., 2010.

18) Package Insert, Ofloxacin Gel Forming Ophthalmic Solution 0.3\% 「Wakamoto」, 3rd ed., Wakamoto Co., Ltd., 2010.

19) Nishimoto Y., Idaka Y., Shibata K., Aikawa T., Bunseki Kagaku, 60, 223-228 (2011) .

20) Miyazaki S., Takeuchi S., Yokouchi C., Takeda M., Chem. Pharm. Bull., 32, 4205-4208 (1984).

21) Higuchi W. I., J. Pharm. Sci., 51, 802-804 (1962).

22) Kato T., Yokoyama M., Takahashi A., Colloid Polym. Sci., 256, 15-21 (1978).

23) Li L., Shan H., Yue Y., Lam C., Tam K. C., Hu X., Langumuir, 18, 7291-7298 (2002).

24) Li L., Macromolecules, 35, 5990-5998 (2002). 